\title{
Feeling Of Insecurity In Working And Non-Working Women Of Pakistan: A Comparative Study
}

\author{
Fareda Zeab \\ Department of Psychology \\ University of Karachi \\ Uzma Ali \\ Institute of Clinical Psychology \\ University of Karachi
}

\begin{abstract}
The purpose of this study is to explore the difference between feeling of insecurity in working and non-working women of Pakistan. It was hypothesized that "The working-women will score higher the non-working women on the variable of feelings of insecurity". The sample of 250 (125 working, 125 non working) women, age range was between 28 years to 45 years $(\mathrm{M}=34.126 ; \mathrm{SD}=4.129)$ were selected from different organizations and areas of Karachi, Pakistan through purposive sampling technique. After taking the permission from authorities and informed consent from the participant demographic forms were filled then in order to measure the feeling of insecurity, Zeab Fareda's Insecurity Scale (2011) was administered, individually. Descriptive statistics and t-test for independent mean were used to analyze the data through SPSS. It was concluded that working women are likely to have feeling of insecurity than non working women in Pakistan.
\end{abstract}

Key Words: Pakistan, Working and Non-Working Women, Insecurity, Psychology

$$
\begin{aligned}
& \text { تلخيص }
\end{aligned}
$$

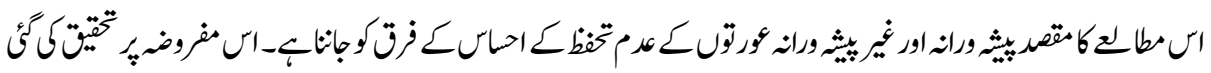

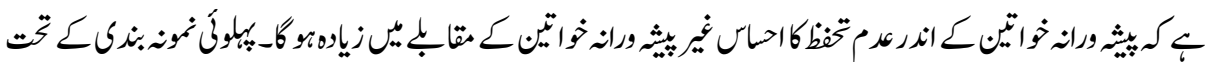

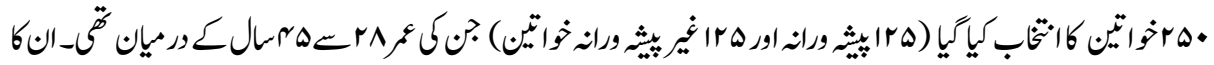

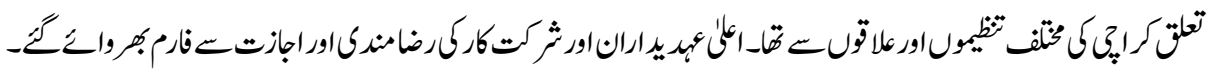

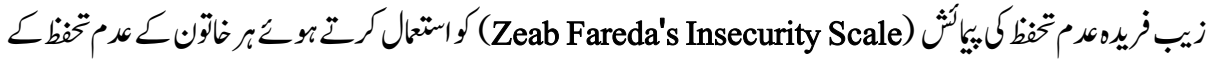

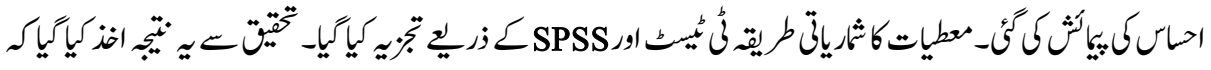

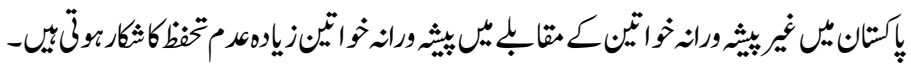

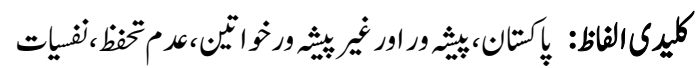




\section{Introduction}

Since, the subject ahead pertains to women's feeling of insecurity; it will be worthwhile discussing the aspects of external influences. It has been established by many researches for instance Ali, Khan and Munaf (2013); Zeba (2011) that ever since the beginning of mankind; males have certain dominancy over females, and free to practice their positions of authority. As the time went by modernization and globalization became popular in societies and the issues of gender based discrimination became popular and politicized but by having different impact on working and non working women. Of late women have been found going through the phase of emancipation by started taking serious stand for their rights and successfully having earned a lot of social, economical, political and other laurels. Working women belonging to developed cities are receiving benefits of such changes while the other category of the women i.e. not working \& the women living in rural areas or belonging to underdeveloped countries (e.g. Pakistan, Bangladesh or India etc) are not well aware of their rights. Even those, who know about their rights, are not allowed to raise their voice and practically not privileged. Either, they consciously lack the basic social, economical and political rights or they are not being allowed to enjoy their freedom (Ali \& Munaf, 2013; Ossai, 2012; Zeab, 2011).

In terms of psychology an emotional response to a perceived danger by threatening stimuli is known as fear or feeling of insecurity (World Health Organization, 2006). Such emotions of insecurity are more strongly felt by female in comparison to male gender. Psychology, further describes the insecurity of being victimized by violent behaviour becomes higher especially when one's perceived vulnerability and sense of helplessness are higher. The subject goes on dilating the fear of violent behaviour which is frequently more common in females than in males due to their experience of sexual crimes which range from sexual annoyance to rape and killing after sex regardless of their belonging to working or non working. The working women, however, face this additional problem of sexual harassment in public places more and make their sexual honour more at risk because of crowded places full of activities (Institute for Digital Research and Education, 2013; Hanam, 2010; World Health Organization, (2006).

Powell (2011) stated in their discussion that currently, the boundaries between working and non-working women are being broken by rising awareness through media, civil society and globalization. The awareness is exerting a positive change in the life of women living in the under developed countries, as well. These studies added that status and treatability of women varies in each socio-economic stratum, city to city, community to community and area to area level. People living in urban areas respect and value their women to be a part of earning member of family and their status is comparatively improved as it was in past (Ossai, 2011, 2012 ; Powell ,2011). 
The findings of some researches e.g. Alavi, (2010) Pakistani women in a changing society, corroborate the earlier observations of Fareda and Mumtaz (2010) had reported a strong correlation between security-insecurity and adjustment problems. Since, working women adopt different roles at home and at work place, they experience sustained stress and anxiety which negatively affect their psychological well-being. Irrespective of the fact that they are earning member of the family, mental distress of women remains unacknowledged within families especially 'Indian families are to be underestimated in mental problem. These women are induced anxiety in them due to the norms, social discipline and the expected roles. These studies referred in that physical and sexual abuse on women exerts a negative long lasting impact on women's physiological and psychological health (Alavi, 2010; Fareda, \& Mumtaz, 2010).

However, according to some other studies like Institute for Digital Research and Education, (2013) on Marital adjustment, stress and depression that to engage in paid work, improved the status of women economically and professionally and has also decreased the sense of insecurity among themselves and made them strong enough to handle difficult situations. There are various other factors which have an impact on their sense of security e.g. job security, working \& social norms. Zeab (2011) added by the study on Feeling of Insecurity in Women that real or perceived threat to women, combined with job and household responsibilities may make them rejected, alienated and tensed. Their feelings of inability, social and interpersonal devoid lead sense of insecurity. Such women feel humiliated, guilty and failure (Institute for Digital Research and Education, 2013; Zeab 2011).

On the one hand, National Centre for Chronic Disease Prevention and Health Promotion (2010) stated in the study which was carried out on working mothers health and house wives that in general there were drawbacks of lack of security for the mental well-being of women. Their mental health is likely to get more affected as they are more sensitive towards criticism and negativity. However, non working women, have lesser exposure and they tend to avoid socially distressing situations, compared to employed females. Social pressure and anxiety combined with fear of negative evaluation deteriorates the mental health of women in general. According to Powell (2011) this thinking of being evaluated by others creates social apprehension in them. The violent behaviours against women also play an important role in their nervousness. Both studies concluded that, although, economic autonomy as well as temporary absence from home are factors which may help the working women to cope effectively. Despite that, once acquired working women's mental health is hampered because of the tendency to avoid distressful situation, which is inevitable in the working situation. Moreover, women who do not work, spend a lot of time with their family members. Hence, their emotional bond is much stronger which helps to remain mentally fit and healthy, as human bonding helps an individual remain healthy and stable mentally. 
Moreover, Abraham (2011); Coleman (2010) agreed that females are at risk gender, however, being working they are financially independent and can take decisions themselves but they are not in practical like that and they mostly rely on their male counterpart for some important decisions even day to day minor decisions. Many studies supported that the females who are living in the cities still facing difficulties of getting admission in schools, institutes and getting jobs. The case in the conventional era in which women were supposed to stay at home and men had to earn the livelihood for their family that is still working out in many areas of Pakistan. They further mentioned that most of females are having multiple skills and talent that goes in vein when they sit idle at home that leads them to feel frustrated and that install feelings of devalue their contribution for household and other out of home activities they performed. For these reasons, Ossai (2011) assumed that female's insecurity at workplace is also common due to the little number of female in the working fields, though the ratio of females is $52 \%$ but their representativeness even less than 33\% and those who are in parliament are not having full power to initiate legislation for the best interests of females and they are subject to male dominance in assemblies as well. Being a passive partner females are more vulnerable to daily life issues such as inflation, unemployment, and poverty.

Ali and Munaf (2013) stated in the paper Attitudes toward Women in Managerial Position in Pakistan that working-women get less attention regarding their physical and mental health as being a working and responsible member of family it is believe that they can take care about themselves and they are physically and mentally sound. In a study Zeab (2011) found that female's mental health is affected by responsibilities at home and other works done outside the home and they suffer from stress frequently. As they have to perform various tasks at home that cause them stress and disturb their psychological well-being.

In contrast Abraham (2011) and Coleman (2010) agreed together with the earlier mentioned some studies reported that employed women possess more sound psychological and mental health status than housewives. It is being concluded that those women who are working and considered that their professional role is a source of selffulfilment scored high on satisfaction with life scale. They further added that employed mothers are psychologically healthier and sound than those mothers who are unemployed.

Nevertheless, there are some studies, e.g. Silva (2010); Alavi (2010) argued that there was no difference found between working and non-working women in the status of psychological well being. Whether or not employment status is worthy and beneficial to women's well-being is still not a firm conclusion. It also depends on some other different variables such as working conditions, organization type, subjective perception of a person, and satisfaction with the job. 
The literature indicates the significance of security and insecurity issues on the mental well-being of female. Although, there is limited studies were carried out across the country on current theme; reports comparative evaluation on security and insecurity among working and non-working women. The research cited in the literature review indicates that a Western evaluation on current issue addressed and it is hard to replicate for the working and non-working segment of Pakistan. Research in this area in Pakistan is negligible and hardly provides any basis for valid assertion about the state of affairs and the remedies.

The objective of the study is to investigate the difference of Feeling of Security and Insecurity among working and non-working women, living in Karachi, Pakistan. Since previous researchers found that working women are more vulnerable to sexual harassment at their work place. They get more stress as compared to non working females, who stay at their homes. Considering the past researches, it was hypothesized that:

There will be a significant difference between working-women and non-working women on the variable of feeling of insecurity.

\section{Method \\ Participants}

The sample for the current study was taken from Karachi city. Since, Karachi is considered as a capital of province named Sindh. Karachi is a multi populated city of Pakistan and the people who belong from different areas around Pakistan come to earn a living for their families here. Since, ample and multi cultured people live in the city the data of this city may has a significant value to generalize as Pakistan's sample. An easily available of targeted women such as teaching, non-teaching staff, women Bankers, paramedical staff and house wives were chosen from various commercial organizations including, Jhangeer Siddiqui Bank Ltd, Cresguard Systems (Pvt) Ltd, Fulcrum pvt Ltd as well as Jinnah Hospital. A total sample of 250 women was taken for the study. It was further broken into two groups of 125 non-working women and 125 working-women. The age range was between 28 to 45 years $(\mathrm{M}=34.12 ; \mathrm{SD}=4.12)$ for entire sample. The sample's minimum level of education was 14 years. The women's socio-economic status (SES) was evaluated by family incomes.

\section{Measures}

\section{a) Demographic Sheet}

In order to explain the implications of the study, researchers must gather the personal information of the participant such as marital status, education, age, income, occupation 
and family structure etc. To collect the demographic information of the subject (women), a demographic form was written and given to the women.

b) Zeab Fareda's Insecurity Scale (Zeab, 2011)

The scale is primarily made up of 12 easy daily life routine questions SUBSCALE. They were given to the women and requested to reply to the statements by using 4-point Likert scale, as false $=0$, slightly true $=1$, mainly true $=2$ and strongly true $=3$.

Reliability and Validity of Insecurity Scale (2011) Insecurity Scale was evaluated applying Cronbarch's $\alpha$. Overall alpha of working and non- working women's is 0.7759 so Cronbach's $\alpha=0.7759$. Finally and perhaps most important value Alpha at the bottom is Cronbach's $\alpha$. The values are looking for in the range 0.7 to 0.8 , so this probably indicates good reliability .Cronbach' $\mathrm{SA}=0.8$ which indicates good reliability. The validity is $100 \%$ confident that its questionnaire's property at the Insecurity scale.

\section{Procedure}

In order to collect the data of working women, first of all, multiple commercial organizations were approached. The organizational heads were explained the purpose of the research and a 'Request of permission to collect the data' was also been asked. The telephonic and e-mail permissions were taken. The letters of consent were given to the non-working females in physical presence. Secondly, in the view of obtained official permission, the samples were approached comfortably and then individually briefed the reason of the research. They were told the ethics of research participation as a volunteer subject. The women were informed that they could withdraw their participation at any time. The confidentiality of the findings was also being rest assured. Thirdly, they were requested to sign the consent form to participate in the research. A demographic form containing personal questions such as age, marital status, education, socio-economic status, income, family structure, occupation, profession was asked to fill. Each participant was interviewed separately (one participant at a time). All of the participant's marital status was constant; married. Finally, Insecurity Scale (Zeab, 2011), was administered on women to measure their subjective feeling of insecurity.

The women, who were taken as a control group in the study, were approached at their homes and universities (students). They had no background history of paid work. The same procedure was applied to gather the information from non-working women, just as for working women. 


\section{Operational Definitions of the Variable Insecurity}

Zeab (2011) defines "insecurity as being unsure, unstable, shaky, apprehensive, or lacking in self-confidence".

\section{Results}

This section shows the statistical outcomes of the research data. Statistical Package of Social Sciences (SPSS) was brought forward to analyze the information. 0.05 was the significant level for entire analysis. In order to evaluate the level of differences among the variable; Feeling of Insecurity, t-test was applied. To interpret the results Descriptive statistics was opted.

The t-test indicates that working-women showed higher mean scores on the variable of Insecurity feelings than the mean scores of non-working women.

Table: 1

Shows frequencies and percentages distribution of non-working and workingwomen regarding to their age that is ranged between 28 years to 45 years

\begin{tabular}{|c|c|c|c|c|c|c|}
\hline Age & \multicolumn{2}{|c|}{$\begin{array}{c}\text { None-Working- } \\
\text { Women }\end{array}$} & \multicolumn{2}{c|}{ Working-Women } & \multicolumn{2}{c|}{ Total } \\
\hline & F & \% & F & \% & F & \% \\
\hline & & & & & & \\
\hline 28 & 5 & 4 & 5 & 4 & 10 & 4 \\
\hline 29 & 4 & 3 & 4 & 3 & 8 & 3 \\
\hline 30 & 16 & 13 & 16 & 13 & 32 & 13 \\
\hline 31 & 14 & 11 & 14 & 11 & 28 & 12 \\
\hline 32 & 6 & 5 & 6 & 6 & 12 & 5 \\
\hline 33 & 10 & 8 & 9 & 7 & 19 & 8 \\
\hline 34 & 13 & 11 & 13 & 10 & 26 & 10 \\
\hline 35 & 13 & 11 & 14 & 11 & 27 & 9 \\
\hline 36 & 9 & 7 & 9 & 7 & 18 & 8 \\
\hline 37 & 8 & 7 & 8 & 6 & 16 & 6 \\
\hline 38 & 2 & 2 & 2 & 2 & 4 & 2 \\
\hline 39 & 11 & 9 & 11 & 9 & 22 & 9 \\
\hline 40 & 5 & 4 & 5 & 4 & 10 & 4 \\
\hline 43 & 4 & 3 & 4 & 3 & 8 & 3 \\
\hline 44 & 4 & 3 & 4 & 3 & 8 & 3 \\
\hline 45 & 1 & 1 & 1 & 1 & 2 & 1 \\
\hline Total & $\mathbf{1 2 5}$ & $\mathbf{1 0 0 . 0 0 \%}$ & $\mathbf{1 2 5}$ & $\mathbf{1 0 0 . 0 0 \%}$ & $\mathbf{2 5 0}$ & $\mathbf{1 0 0 . 0 0 \%}$ \\
\hline
\end{tabular}


Table: 2

Shows the Mean and Std. Deviation of age of working and non-working women in Pakistan

\begin{tabular}{|c|c|c|c|}
\hline \multirow{2}{*}{ Occupations } & Non-Working- & Working- & \multirow{2}{*}{ Total } \\
\cline { 2 - 4 } & Women & Women & \\
\hline N & 125 & 125 & 250 \\
\hline Mean & 34.46 & 34.47 & 34.126 \\
\hline Std. Deviation & 4.138 & 4.136 & 4.129 \\
\hline
\end{tabular}

Table: 3

Shows frequencies and percentages of non-working and working-women according their education and main subjects, e.g. commerce, arts, business and computer sciences

\begin{tabular}{|c|c|c|c|c|c|c|}
\hline Education & \multicolumn{2}{|c|}{$\begin{array}{c}\text { Non-Working } \\
\text { Women }\end{array}$} & \multicolumn{2}{l|}{ Working Women } & \multicolumn{2}{c|}{ Total } \\
\hline & F & $\%$ & F & $\%$ & F & $\%$ \\
\hline & & & & & & \\
\hline B.Com & 64 & 51.2 & 16 & 12.8 & 80 & 3.2 \\
\hline BA & 1 & .8 & 6 & 4.8 & 7 & .3 \\
\hline BBA & 6 & 4.8 & 4 & 3.2 & 10 & .4 \\
\hline BDS & 3 & 2.4 & 12 & 9.6 & 15 & .6 \\
\hline BSc & 9 & 7.2 & 13 & 10.0 & 22 & 0.9 \\
\hline LLB & 1 & .8 & 19 & 15.2 & 19 & .8 \\
\hline MA & 6 & 4.8 & 6 & 4.8 & 7 & .3 \\
\hline M.Com & 2 & 1.6 & 5 & 4.0 & 11 & .4 \\
\hline MA I.R & 3 & 2.4 & 9 & 7.2 & 9 & .4 \\
\hline Master & 30 & 24.0 & 15 & 12.0 & 17 & .7 \\
\hline MBBS & -- & -- & 11 & 8.8 & 14 & .6 \\
\hline MSc & -- & -- & 9 & 7.2 & 39 & 1.6 \\
\hline Total & $\mathbf{1 2 5}$ & $\mathbf{1 0 0 . 0 0 \%}$ & $\mathbf{1 2 5}$ & $\mathbf{1 0 0 . 0 0 \%}$ & $\mathbf{2 5 0}$ & $\mathbf{1 0 0 . 0 0 \%}$ \\
\hline
\end{tabular}


Table: 4

Shows frequencies and percentages of working-women according their profession

\begin{tabular}{|c|c|c|c|c|}
\hline Designation & Frequency & Percent & Valid Percent & $\begin{array}{c}\text { Cumulative } \\
\text { Percent }\end{array}$ \\
\hline Paramedics & 12 & 9.6 & 9.6 & 9.6 \\
\hline Advocate & 13 & 10.4 & 10.4 & 20.0 \\
\hline ASM Pahrma & 9 & 7.2 & 7.2 & 27.2 \\
\hline Banker & 9 & 7.2 & 7.2 & 34.4 \\
\hline Doctor & 23 & 18.4 & 18.4 & 52.8 \\
\hline Field Work & 5 & 4.0 & 4.0 & 56.8 \\
\hline $\begin{array}{c}\text { Health } \\
\text { Supervisor }\end{array}$ & 6 & 4.8 & 4.8 & 61.6 \\
\hline MM & 9 & 7.2 & 7.2 & 68.8 \\
\hline Officer & 6 & 4.8 & 4.8 & 73.6 \\
\hline Social Worker & 9 & 7.2 & 7.2 & 80.8 \\
\hline Teacher & 24 & 19.2 & 19.2 & 100.0 \\
\hline & & & & \\
\hline Total & $\mathbf{1 2 5}$ & $\mathbf{1 0 0}$ & $\mathbf{1 0 0}$ & \\
\hline
\end{tabular}

Table: 5

Mean Scores of working and Non-Working Women on the variable of Insecurity.

\begin{tabular}{|c|c|c|c|c|c|c|}
\hline Variable & $\mathbf{N}$ & $\mathbf{M}$ & SD & SEM & t & Sig \\
\hline Insecurity & & & & & & \\
\hline Non-Working & 125 & 18.01 & 4.86 & 0.43 & -7.54 & .000 \\
\hline Working & 125 & 22.03 & 3.4 & 0.43 & & \\
\hline
\end{tabular}

Note: $d f(248) ; p<.000 * * *$

The above table shows that the mean value (working) is greater than mean value (nonworking), and standard deviation shows that precision in working women that is why working women standard error of mean is low. P-value less than level of significant shows that, There is statistically difference in the mean scores of working and nonworking women on the variables of Insecurity, where working women score higher than non-working women.

The p-value is maximum probability accoutring in true value is probability-value is less than level of significance its mean significant relation between variables. 


\section{Discussion}

The objective of present research paper is to highlight the difference of feelings of insecurity between working and non working women in Karachi, Pakistan. The statistical analysis of the scores, suggest that working-women on the variable of feeling of insecurity found comparatively more insecure than their counterparts; non-working women (table 5). "Working women's feeling of insecurity dynamically appears in four dimensions including: insecurity feeling regarding instability of income, protection from crime, predictability of one's daily life, and psychological insecurity" (Zeab, 2011). To counter the rational, Shireen \& Zeba (2010) quoted the agreeing statement of Murray (1938) concentrating on working women, if picks up relevant material from a woman of working background, feels themselves rejected and isolated due to the preoccupation with actual or perceived threat of handling dual responsibilities of home and of work place. This feeling of incompetency and social withdrawal leads towards feeling of uncertainty, embarrassment, shame, rejection, and disappointment. To study the impact of work place on the health of women no matter they are urban or rural, it will be worthwhile referring to the work of wide range work on the issue of women work \& mental health, who in their studies attempted to explore the impact of work status of female on their health. Though, they also earn a living for the family but no one in the family cares them emotionally.

\section{Conclusions}

In the view of the results of the current study, it may be concluded that lack of awareness of women rights, lack of education and the paucity of resources affect the women's mental health negatively.

It has discussed in the literature review further, with reference to results of workingwomen that the higher scores on variable of feeling of insecurity of the working females urge the need to review the policies. According to the results, employed women's have better mental health condition than non-employed, one points out the urge to providing the emotional security to the working-women.

\section{Recommendations}

In the view of the current results, it may be suggested that the working conditions especially for women in Pakistan should be urgently improved. The policies of transport safety, job security, compliance the law and daily routine predictability should be imposed. The women of Pakistan may play a substantial role to bring the economic revolution, since; they are in majority i.e. $52 \%$ of whole population. 
A research is a necessity in order to pin point the issues of working women such as the sense of insecurity among them and among those who are under immense pressure. Environmental insecurities are more likely to prevail among working women and they have no way of social or emotional discharge in order to give them relief.

There is a need to have a regular examination of the problems, not only at their work place but also their residence as they are prone to face serious level of insecurities at both places. Hence, diverse aspects queries are required.

To conclude it will not be wrong to say that the findings of the study suggested that there were some factors which effect Pakistani women and leave them with a feeling of insecurity such as instability of income, protection from crime, psychological insecurities and the daily routines. The sample group should include some major cities across Pakistan. It will give expansion to the study and also various professions may be included in future studies. Lastly, future studies should strongly requisite consideration of the relationship of important demographic variables with feeling of insecurity among women.

This study may be very beneficial for not only having a healthy organizational culture but also for societies and household issues.

\section{Acknowledgements}

I am very grateful to Ms Gail Rowntree, lecturer Business Administration, Bucks New University (BNU), UK under whose guidance the Zeab Fareda's Insecurity Scale was developed. I am also thankful to the participants and authorities of different organizations in Karachi, Pakistan for their cooperation in data collection.

\section{References}

Abraham, A. (2011). Isolation as a form of marital violence: Journal of Social Distress and the Homeless, 20 (22), pp. 221-226.

Alavi, H. (2010). "Pakistani women in a changing society”. [Accessed 24 August 2013] Retrieved from: http://ourworld.compuserve.com/homepages/sangat/pakwomen. htm

Ali, U., Khan, A., \& Munaf, S. (2013) Attitudes toward Women in Managerial Position in Pakistan: International Journal of Information and Education Technology, 3 (3), pp. 373-377. 
Boston University School of public Health (2013). "The theory of planned behaviour". Retrieved from http://sph.bu.edu/otlt/MPH-Modules/SB/SB721-Models/SB721Models3.html

Coleman, E. (2010). Working for Peanuts: Nonstandard Work and Food Insecurity A cross Household Structure, Journal of Family and Economic Issues, vol. 32 (1), pp. 84-97.

Esomonu, J.C. (2010). The relationship of employment to self-perception and well-being in women: A cognitive analysis . Journal of Teacher Education and Teaching, vol. 8 (1), pp. 360-366.

Fareda, S., \& Mumtaz, K. (2010). Women's Economic Participation in Pakistan. Status Report for UNICEF Pakistan. Accessed on September 3 2013, http://eprints.hec. gov.pk/442/1/151.html.htm

Hanam, B, (2010). The Study of Determinants and Correlation of Job Satisfaction and Living Satisfaction: The Labour and Economy, 23 (1), 93-126, the Korean Labour and Economy Society. Retrieved from http://www.highbeam.com/doc/iGi306182802.html [Accessed on August 21 2013].

Institute for Digital Research and Education, UCLA. (2013). Retrieved from http://www.ats.ucla.edu/stat/SPSS/faq/alpha.html [Accessed on August 3rd 2013]

National Center for Chronic Disease Prevention and Health Promotion, (2010). the burden of chronic diseases, their risk factors, National, State Perspectives, 2004. Atlanta, GA: USDHHS.

Ossai, M.C. (2011). Perspectives on working women: Bureau of Labour Satistic. Mediterranean Journal of Social Sciences, vol. 2, pp. 23-28.

Ossai, M.C. (2012). Age and gender difference in study habits: A framework for proactive counselling against low academic achievement. Journal of Educational and Social Research, vol. 2, pp. 67-73.

Powell, E. (2011). The relationship between age and deep level study habits in a vocational nursing program (unpublished Graduate Research Project). Department of Curriculum and Instruction, Sam Houston State University, USA.

Shireen, J. \& Zeba, S. (2011). Women's Autonomy in India and Pakistan: the influence of Religion and Region, Population and Development Review, vol. 27(4), pp. 687-712. 
Silva, C. N. (2010). The association between economic and social factors and mental health. Retrieved: from www.knoweldge.sagepub.com/view/researchdesign/n 145.xml.D01 :10

World Health Organization. (2006). Women's Mental Health: A Public Health Concern. Retrieved July 4, 2013, from http://www.searo.who.int/EN/Section1243/ Section1310/Section1343/Section1344/Section1353_5282.htm

Zeab, F. (2011). Feeling of security-insecurity in working-women \& non-workingwomen in Pakistan, Post Graduate Unpublished thesis, Bucks New University (BNU), UK.

Fareda Zeab is Ph.D fellow in the Department of Psychology, University of Karachi.

Dr. Uzma Ali is Associate Professor in the Institute of Clinical psychology, University of Karachi. 